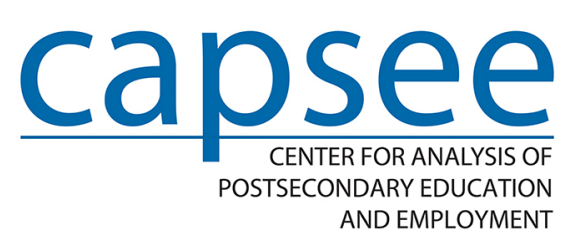

\title{
The Medium-Term Labor Market Returns to Community College Awards: Evidence From North Carolina
}

\section{A CAPSEE Working Paper}

\author{
Clive Belfield \\ Queens College, City University of New York \\ Yuen Ting Liu \\ Community College Research Center \\ Teachers College, Columbia University \\ Madeline Joy Trimble \\ Community College Research Center \\ Teachers College, Columbia University
}

March 2014

The research reported here was supported by the Institute of Education Sciences, U.S. Department of Education, through Grant R305C110011 to Teachers College, Columbia University. We are grateful for excellent feedback from Shanna Jaggars, Di Xu, and attendees at the 2012 CAPSEE Conference as well as the editing expertise of Amy Mazzariello and Doug Slater, both of which improved this paper immensely. The opinions expressed are those of the authors and do not represent views of the Institute or the U.S. Department of Education.

For information about authors and CAPSEE, visit capseecenter.org 


\begin{abstract}
In this paper, the authors examine the relative labor market gains for first-time college students who enrolled in the North Carolina Community College System in 2002-03. The medium-term returns to diplomas, certificates, and degrees are compared with returns for students who accumulated college credits but did not graduate. The authors also investigate the returns to credit accumulation, subject field, and transfer and the early trajectories of wages for different student subgroups during the 2000s. The analysis is based on student-level administrative record data from college transcripts, Unemployment Insurance wage data, and enrollment and graduation data from the National Student Clearinghouse across 830,000 community college students between 2001 and 2010. Findings from this study confirm those from earlier work: The returns to certificates and diplomas were weak, but associate and bachelor's degrees yielded very strong returns; even small accumulations of credits had labor market value; and the returns to health sector credentials were extremely high. Returns were much higher for female students than for male students. Despite the Great Recession, analysis reveals little evidence that the returns to college decreased over the latter half of the 2000s. However, medium-term estimates likely understate the full value of college credentials, particularly bachelor's degrees.
\end{abstract}




\section{Table of Contents}

$\begin{array}{ll}\text { 1. Introduction } & 1\end{array}$

2. The Labor Market Gains From Community College 2

Evidence on Labor Market Gains From Community College $\quad 2$

Method for Estimating Labor Market Returns 4

3. Data $\quad 5$

Datasets

$\begin{array}{ll}\text { Descriptive Frequencies } & 7\end{array}$

$\begin{array}{lr}\text { 4. Results } & 8\end{array}$

Labor Market Returns Nine Years After Enrollment $\quad 8$

The Trajectory of Labor Market Returns Over the Decade 17

Employment Effects of Awards $\quad 22$

$\begin{array}{ll}\text { 5. Discussion and Conclusion } & 23\end{array}$

$\begin{array}{ll}\text { References } & 25\end{array}$

$\begin{array}{lr}\text { Appendix } & 29\end{array}$ 



\section{Introduction}

Extensive research has shown that a college education has substantial value in the labor market (see the general review by Altonji, Blom, \& Meghir, 2012; and, on community colleges, Belfield \& Bailey, 2011). Yet, most of the evidence is on the value of a bachelor's degree or on outcomes for an amorphous and heterogeneous category, those with "some college." This category includes students who earn associate degrees or occupational credentials, as well as those who drop out of college or transfer from a community college to a four-year institution but fail to complete a degree. Little is known about the returns for students who do not follow a direct path from high school to college to the labor market or who obtain sub-degree awards, such as certificates or diplomas.

In addition, evidence on past returns may be of limited relevance for current student cohorts as a result of recent changes in the labor market and in the postsecondary education sector. Over the past two decades, there have been a number of changes in the skill composition and wage structure of the labor market, which have been amplified by the Great Recession. In conjunction with increases in college tuition and student debts, these changes are likely to have significant repercussions on the economic value of college - particularly for those students in the "some college" category. At the same time, students' options for pursuing a postsecondary education have expanded. An increasing number of students are receiving new short-term vocational credentials, which are often delivered in a hybrid modality, partly in class and partly online. These changes signal a need for more research on the returns to the various educational pathways that are currently available to students.

In this paper, we estimate the labor market returns across various college awards for recent cohorts of community college students in North Carolina. Using detailed administrative data merged with independent earnings data, we estimate the labor market returns to college in the 2000s for students who began their postsecondary studies at a community college. Thus, we are able to calculate labor market gains, controlling for covariates across a large sample of recent students who attended college but in most cases did not earn a bachelor's degree.

Our paper is structured as follows. First, we review the relevant literature and discuss the methodological challenges involved in estimating the returns to college; we also describe our method for analysis. Next, we describe the datasets used in our analysis. We then present our main results, followed by a series of subsample analyses and robustness checks. In the final section, we offer some conclusions and note areas for further investigation. 


\section{The Labor Market Gains From Community College}

\section{Evidence on Labor Market Gains From Community College}

Belfield and Bailey (2011) summarized the published evidence on the labor market gains from community college. Generally, there are positive returns across most awards. Across 18 studies, the average earnings premium for an associate degree compared with a high school diploma is 13 percent for men and 21 percent for women. Vocational certificates are also associated with higher earnings (Marcotte, Bailey, Borkoski, \& Kienzl, 2005). A few studies have found earnings gains from credits or years of study at community college that do not lead to a completed degree; gains are identifiable for as little as a semester's worth of credits (Jacobson, Lalonde, \& Sullivan, 2005). Earnings gains vary significantly across different subjects of study (defined retroactively based on awards); the general consensus is that the returns are higher for quantitative or technical-vocational courses.

Overall, the rate of return to postsecondary education is high (Carneiro, Heckman, \& Vytlacil, 2011), but returns may vary across groups of college enrollees. For example, very recent graduates may have lower returns (Henderson, Polachek, \& Wang, 2011). Until recently, most of the evidence on community college students came from small-scale surveys that precluded extensive subgroup analysis (e.g., by certificate field) and relied on datasets collected in the 1970 s and 1980 s.

Subgroup analysis is important because students take many pathways to accumulate human capital within the community college system. Students enroll with varying intensity, combining part-time enrollment and hiatuses from college with employment. ${ }^{1}$ Many community college students begin their studies in remediation: 40 percent of students take at least one remedial course, and many never progress to take college-level courses (Bailey, Jeong, \& Cho, 2010; Horn \& Nevill, 2006, Table 6.2). One third of all students transfer, typically without obtaining a credential at their college of first enrollment, and many students enroll in community college after beginning their studies at a four-year institution (Hossler et al., 2012). Many students take credits that are not required, either because they are unsure of the program requirements or because they cannot access the necessary courses (Romano, Losinger, \& Millard, 2011). Finally, the composition of awards is changing. Increasingly, students are pursuing short-term certificates or diplomas rather than two-year associate degrees; certificate awards grew by 56 percent between 2000 and 2009, whereas degree awards increased by only 39 percent during the same period (Bailey \& Belfield, 2012). Of course, the majority of students do not complete any program. Across all two-year institutions, only 30 percent of the cohort that entered college in 2007 completed an award within 150 percent of normal time (Snyder \&

\footnotetext{
${ }^{1}$ For the students in our sample, transcript data show that the most common enrollment pattern is part-time for one semester. Few students follow the convention of two years of uninterrupted full-time study with a break in the summer.
} 
Dillow, 2012, Table 345). With such wide variation in students' college trajectories, it is especially critical to estimate the returns to college for specific pathways. ${ }^{2}$

Many factors may have influenced the rate of return to college in recent years, both in general and for subgroups of workers. On the demand side, there has been a general increase in skill-biased technological change, as well as changes in the need for particular occupations and changes in industry structure (Carnevale, Smith, \& Strohl, 2009; Goldin \& Katz, 2008). The biggest changes have occurred as a result of the Great Recession. Between 2007 and 2009, employment of young workers declined by 12 percent (double the rate of employment decline for older workers). At the same time, significant industrial changes took place: Employment decreased in construction by 19 percent and in manufacturing by 13 percent, but it increased in health care by 3 percent (Mulligan, 2012, Table 2.1). For workers with "some college," the job loss rate in 2007-09 was 4 percent, although this loss was subsequently offset by a job gain rate of 4 percent in 2010-12 (Carnevale, Jayasundera, \& Cheah, 2012, Table 3). The job loss and subsequent gain were much sharper for men, who began entering female-dominated occupations at greater rates in the wake of the recession (Carnevale et al., 2012). The Great Recession may therefore have affected returns for cohorts entering the labor market in the latter half of the decade (Davis \& von Wachter, 2011; Kahn, 2009).

On the supply side, changes in the higher education sector may have altered the human capital students acquire. These changes include the reduction in public funding, the shift toward online learning, and the growth of for-profit colleges (Bailey, 2012). Student quality is also likely to be a mediating factor. If students are less productive at generating human capital, their returns from college will be lower (on changes in ability bias, see Kaymak, 2009). Changes in student quality may be reflected in longer time to completion or in less time spent on learning in college (Babcock \& Marks, 2011; Bound, Lovenheim, \& Turner, 2010).

Several recent studies have begun to identify the returns to the range of awards offered by community colleges using large-scale datasets. These studies follow earlier work by Jacobson et al. (2005) using unemployment insurance data on displaced workers from Washington State in the 1990s. Jepsen, Troske, and Coomes (2011) estimated the returns to community college awards in Kentucky, and Dadgar and Weiss (2012) identified the labor market returns to more recent cohorts of all community college students in Washington State. Andrews, Li, and Lovenheim (2012) estimated the returns to community college relative to graduation from a four-year institution in Texas. An important distinction between these newer studies and earlier studies is that the newer studies make comparisons within the sample of postsecondary students and not between postsecondary students and high school graduates who never attended college. The newer studies affirm most of the earlier findings: Returns to associate degrees are high, particularly in the health sciences, and gains for female students exceed those of male students. However, they reveal more

\footnotetext{
${ }^{2}$ It is not possible to investigate the returns to all pathways in this paper. Estimations of the returns to nursing programs, developmental education, and remediation will be performed in a series of companion papers.
} 
heterogeneous returns to certificates and diplomas, as well as to particular fields of study. Our study, which also compares groups of students who began their postsecondary education in community college, provides complementary evidence for North Carolina.

\section{Method for Estimating Labor Market Returns}

We estimate the returns to community college pathways using a standard Mincerian earnings equation:

$$
Y_{\mathrm{t}}=\alpha+\theta E D U C_{\mathrm{t}-\mathrm{k}}+\beta X_{\mathrm{t}-\mathrm{j}}+\gamma Z_{\mathrm{t}-\mathrm{k}}+\delta E X P_{\mathrm{t}}+\varphi E X P_{\mathrm{t}}^{2}+\varepsilon
$$

Earnings $Y$ at quarter $t$ are a function of: college education, $E D U C$, represented as, for example, awards or credits; a vector of prior college characteristics, $Z$; a vector of pre-college personal and ability-related characteristics, $X$; and work experience, EXP. The coefficient $\theta$ represents an estimate of the earnings premium from education obtained in community college. We report quarterly earnings gains in dollars but also express the results as percentage gains over baseline.

The extent to which $\theta$ is an unbiased estimate of the gains from education depends on the extent of omitted variable bias, or whether observed earnings premiums are actually a return to unobserved characteristics (Arcidiacono, 2004; Brand \& Xie, 2010), and the extent of selection or endogeneity bias, or whether earnings are conditional on unobservable factors influencing individual choices about college, when to begin work, or where to work after college (Black, Kolesnikova, \& Taylor, 2009). Though the standard Mincerian earnings function does not fully address these biases, results using this method have proved to be highly robust (as in studies similar to ours, e.g., Dadgar \& Weiss, 2012; Jepsen et al., 2011). The consensus is that at least some of these biases do not significantly distort the results obtained from a simple earnings function (see, e.g., Carneiro et al., 2011). Yet, although this conclusion may be valid in general, it may not be valid when estimating gains to particular pathways with more rigorous academic requirements or to awards with greater portability in the labor market. Its validity may also be questioned when the comparison group is students who dropped out of college (rather than those who never enrolled).

Given that all students in our sample initially enrolled at a community college, we might expect less omitted variable bias than would occur if the comparison group were high school graduates; students in the sample should be fairly similar because all had adequate academic standing and were motivated to attend college. However, many community college students place into remediation (or are completing high school credits), and a proportion may therefore have lower academic standing than high school graduates. Further, some community college students may be motivated to enroll because they cannot find work. Employed high school graduates might therefore have higher productivity. In terms of decision-making skills, high school graduates may be more perceptive as to their ability to complete college. Thus, although it is unlikely, we cannot rule out the possibility that our comparison group (community college 
dropouts) has lower expected productivity than a group of high school graduates who never enrolled in college.

It is also possible that endogeneity bias is present in our sample. In theory, all students in the sample faced similar labor market options because they began college at the same time (and in the same state). However, these students pursued awards of different lengths and studied at different paces; critically, many were employed while they were in college. Hence, the returns to college may depend on the dynamic complementarity between human capital obtained in college and work experience (Flores-Lagunes \& Light, 2010; Henderson et al., 2011). For example, students who study full-time but do not work may have lower future earnings than students who balance college with a significant job commitment. The latter group may apply their human capital skills more immediately in their jobs. Given the many college pathways and work arrangements, modeling the complementarity between human capital and work experience is complex. Here, for simplicity, we follow the conventional approach of assuming that human capital gained in college and work experience are independently associated with earnings.

\section{Data}

\section{Datasets}

Our dataset is composed of all first-time-in-college, credit-seeking students in the North Carolina Community College System (NCCCS) in the academic years 2001-02 through 2009$10 .^{3}$ The NCCCS includes 58 colleges and enrolls approximately 100,000 new curriculum (award-seeking) students each year. For the timeframe under study, transcript data were available for approximately 830,000 students, although here we predominantly analyze data for the cohort of students who entered college in the 2002-03 academic year, had transcript data available, and were successfully matched with at least some earnings records data (approximately 80,000 students). The dataset contains information on individual students, including full college transcripts (e.g., courses taken, grades earned, awards received, duration of study), basic personal information (e.g., age, gender, race/ethnicity), and financial aid received (loans and grants per semester). The transcript data do not include direct information on socioeconomic status, either

\footnotetext{
${ }^{3}$ We exclude students who were not enrolled in designated curriculum programs leading to awards but in customized training, personal enrichment courses, or other noncredit programs. Although the majority of headcount students were in non-curriculum programs, these students comprised a smaller fraction of full-time equivalent enrollment (North Carolina Community College System, 2007). Compared with national standards, NCCCS tuition is relatively low and state and local support high; student fees represent only 13 percent of total funding (North Carolina Community College System, 2007, p. 9).
} 
of students or their families; on students' prior academic achievement; or on the quality of their schooling. ${ }^{4}$

We merged the college transcript data with student-level data from the National Student Clearinghouse (NSC). The NSC tracks students as they transfer to other Title-IV eligible colleges, as more than one third of all community college students do (Hossler et al., 2012). The NSC dataset includes information on institutions attended, enrollment durations, awards obtained, and field of study at each institution subsequent to enrollment within the NCCCS; however, field of study is not reliably recorded across all colleges.

Our analysis focuses on the highest award obtained by each student at any institution within the designated time period. NCCCS awards include certificates, with 12-18 semesterhour credit requirements, which are intended to be completed in one year of full-time study or less; diplomas, with credit requirements ranging from 36-48 semester-hour credits, with a general education requirement; and associate degrees (mostly in applied science), with a required 64-76 semester-hour credits and a cross-disciplinary general education requirement of 15 semester-hour credits. In addition, the NSC data allow for the identification of NCCCS students who eventually obtained a bachelor's degree or higher and those who obtained any of the other three awards at a transfer college. ${ }^{5}$ We compare students in the four award groups with students who enrolled in an NCCCS college but received no award either within the NCCCS or at a transfer institution within the time period under study.

Using Social Security numbers, we then merged this combined student dataset with earnings data obtained from the North Carolina Department of Commerce Unemployment Insurance (UI) records. The UI earnings data are collected on a quarterly basis from UI-covered employers and include total earnings from all jobs, as well as Standard Industrial Classification

\footnotetext{
${ }^{4}$ Financial aid variables serve as proxies for family background. However, the association between income and community college enrollment is modest. Students in both the bottom and top quartiles of family income enroll in two-year colleges at the same rate (6 percent). In contrast, the enrollment rate at four-year colleges varies with family income, from 13 percent for the bottom quartile to 49 percent for the top quartile (Kinsler \& Pavan, 2011, Table 4; but see Lovenheim \& Reynolds, 2011). In lieu of controlling for prior academic achievement or school quality, we included controls for students' first-semester grade point average (GPA) in community college. School quality and school performance influence college performance (Cyrenne \& Chan, 2012) but do not seem to influence the returns to college. After adding controls for school performance, school fixed effects, and parental income, Marcotte (2010, Table 3) found that the returns to some awards were actually higher than those predicted in other models. We do have high school GPA information for a subsample of students who entered college in 2008. However, our earnings data extend only to 2011, which is too early to identify labor market gains for these students - not least because high school GPA is positively associated with persistence in college. Indeed, estimates for this subsample show a negative association between earnings in 2011 and high school GPA (details are available from the authors).

${ }^{5}$ The match rate between the two datasets is very high, although we cannot identify if a student is missing from the NSC dataset. There is some discrepancy between the NSC and NCCCS datasets with regard to awards. The NSC dataset is more likely to under-tally awards. From the NSC dataset, awards are inferred if a student received that award based on keyword searches for the degree type and its common abbreviations. For this analysis, awards are assigned if the student is ever found to have received that award in either dataset. A small proportion of associate degrees were obtained after transfer to another college.
} 
(SIC) and North American Industry Classification System (NAICS) information for each job (hours of work are not available). Data are available for the period from the first quarter of 1996 (i.e., before any of our cohorts enrolled in college) to the first quarter of 2012. All earnings are adjusted for inflation to be expressed in 2010 dollars using the quarterly Consumer Price Index for Urban Wage Earners and Clerical Workers (CPI-W). This dataset yields over 5 million quarters of earnings data across the 830,000 students.

Unlike sample survey data, UI earnings data are not affected by biases due to imputation, self-reporting, and nonresponse (Bollinger \& Hirsch, 2006; Schmitt \& Baker, 2006). However, the UI data do not include all workers; they exclude independent contractors, military personnel, some federal personnel, and those working in the informal sector (e.g., casual laborers). Analysis of Bureau of Labor Statistics data suggests that approximately 10 percent of civilians are not included in the UI data, primarily because they are independent contractors (see Stevens, 2007). In most states, including North Carolina, state UI datasets do not include workers who moved out of state. Overall, UI coverage is reasonably high: 775,000 of the 830,000 persons ( 93 percent) had at least one UI wage record during the period from 1996-2012. Individuals with no wage record between 1996 and 2012 are excluded from our analysis. ${ }^{6}$

Our primary focus here is on the 2002-03 NCCCS entry cohort, and we report all analyses separately by gender. ${ }^{7}$ For the 2002-03 cohort, we have nine years of NCCCS and NSC transcript data; we also have earnings data up to six years' prior to enrollment (1996) and up to nine years after enrollment (2011), a period which includes the Great Recession. As we show below, however, even this labor market window may be too short to capture the full labor market effects of all awards.

\section{Descriptive Frequencies}

Descriptive frequencies for the merged datasets are given in Appendix Table 1. Frequencies are for the 2002-03 cohort and are split by gender and by highest award status. By 2011, the average quarterly earnings of those who never earned an award but were employed were $\$ 5,190$ for women and $\$ 6,909$ for men. Unadjusted earnings were considerably higher for those with associate degrees ( $\$ 7,232$ and $\$ 8,326$ for women and men, respectively) and for those with bachelor's degrees or above $(\$ 7,634$ and $\$ 8,529$, respectively).

Overall, 37 percent of female students and 33 percent of male students obtained at least one award. Of the awardees, 45 percent of the female students obtained associate degrees as their highest award, and 36 percent obtained bachelor's degrees; the rates for male students are 35 percent and 38 percent, respectively (approximately one third of bachelor's degree recipients also

\footnotetext{
${ }^{6}$ Of those with no UI data, 14 percent were failed matches because of inconsistencies in Social Security numbers. When we estimate models including persons with zero earnings in all quarters, the returns to awards are slightly higher than those reported here (see similar findings by Jepsen et al., 2011). Statistical significance tests are unaffected.

${ }^{7}$ In a further analysis using alternative estimation techniques, we include more NCCCS cohorts.
} 
earned an associate degree). The aggregate bachelor's degree completion rate among NCCCS students is very close to the national average of 15 percent (Shapiro et al., 2013). For the NCCCS sample, certificates and diplomas comprised more than one fifth of all awards; certificate holders were disproportionately male. As shown in Appendix Table 1, those students who did not obtain an award were more likely to be ethnic minorities, older, and more disadvantaged (with a lower expected family contribution) and to have lower grades in their first semester of college.

The data show that community college students accumulated significant numbers of remedial and college credits beyond the award requirements. Women who did not obtain an award had on average 21 credits and men 20 - or enough to satisfy the credit requirement for a certificate, at least in absolute terms. However, all NCCCS award holders accumulated considerably more college credits than required: 29 (men) to 38 (women) for certificates, 56 (men) to 65 (women) for diplomas, and 77 (men) to 81 (women) for associate degrees. Thus, even if these students all attended full-time, they spent considerably more time in college than is stipulated (and a small proportion remained enrolled for nine years). Students who eventually earned a bachelor's degree accumulated 31 (women) to 33 (men) NCCCS credits on average before transferring.

Credit accumulation patterns also varied significantly by gender. For a given award, female award holders accumulated significantly more credits than did male award holders, earning nine more credits for certificates, ten more credits for diplomas, and five more credits for associate degrees. Thus, the greater returns to awards for women may in part reflect the extra credits they accumulated per award. Yet women who did not complete a credential had only slightly more credits than male non-completers; and women who eventually earned a bachelor's degree transferred with slightly fewer credits than males. This pattern suggests that female students may be more efficient at determining their college career, as well as more persistent in working toward an award. (Female students also reported clearer intentions and goals, as shown in Appendix Table 1.)

\section{Results}

\section{Labor Market Returns Nine Years After Enrollment}

Table 1 shows the labor market returns to awards for the 2002-03 cohort in 2011, or nine years after first enrollment. Returns are based on the average of non-missing quarterly earnings, and award status is based on the highest award achieved. To illustrate the effects of covariates, four stepwise specifications are reported. The full specification (column 4) includes controls for student 
background characteristics (including work experience), ${ }^{8}$ college fixed effects, ability in college, and students' intentions and goals (see table notes and Appendix Table 1). This is the preferred specification, and subsequent results are presented using this specification. However, the inclusion of the full set of covariates does not substantially alter the coefficients (as also found by Jepsen et al., 2011); the results of the other specifications, displayed in columns 1-3, are similar.

Relative to the returns for students who accumulated credits but did not earn an award at any college, the labor market returns to some awards were very high. For both female and male students, there were no earnings gains from obtaining a certificate, even though on average female certificate holders obtained 16 more credits and male certificate holders 9 more credits than nonawardees. In fact, earnings were \$347 and \$279 lower per quarter for female and male certificate holders than for students with credits but no award. Women gained from earning a diploma; their earnings were $\$ 1,680$ higher than those of women with just credits. But men did not gain from earning a diploma; despite accumulating 36 additional college credits, award holders had earnings that were $\$ 545$ lower than those of non-awardees. As we show below, these results are partially driven by choices in subject field. In addition, as we show below, certificates and diplomas did give a temporary boost to earnings; the lack of positive returns in 2011 shown in Table 1 reflect the fact that the productivity gains from these awards dissipated after a few years.

Unambiguously, the gains to earning an associate degree were substantial: Wage gains for associate degree holders in 2011 were 61 percent for women and 25 percent for men. ${ }^{9}$ Female associate degree holders earned \$2,136 more per quarter, and male associate degree holders earned $\$ 1,115$ more. The earnings benefits of an associate degree varied substantially by type. A sub-analysis (not reported here) suggests gains were concentrated among students who received Associate in Sciences (AS) degrees. Women who had an AS degree earned \$2,560 more per quarter than baseline students, and men with an AS degree earned \$1,490 more. For women who had an Associate in Arts (AA) degree, there was an earnings gain of \$520; for men with an AA, there was no statistically significant earnings gain over baseline.

Finally, for students who transferred from an NCCCS college to a four-year institution and completed a bachelor's degree, the earnings gains were 68 percent for women and 41 percent for men, ${ }^{10}$ or $\$ 2,284$ and $\$ 1,588$ per quarter, respectively. In general, the returns to awards for female students were significantly higher than those for male students; this finding corresponds to the

\footnotetext{
${ }^{8}$ Work experience includes two components: first, the number of years worked prior to college entry beginning with 1996, the earliest year for which we have UI records; and second, an estimate of the number of years worked prior to 1996, obtained by multiplying the number of years an individual was age 18 or older prior to 1996 by the proportion of quarters worked after 1996 but before college entry.

${ }^{9}$ These gains are calculated only for students whose highest award was an associate degree. If the specification is re-estimated to include all students who received an associate degree-some of whom are in the bachelor's degree category in Table 1-their labor market gains increase by 2-3 percentage points. Thus, an associate degree appears to carry option value in the labor market (Stange, 2012).

${ }^{10}$ Thus, a nontrivial proportion of associate degree holders obtain returns that exceed those of bachelor's degree awardees (as found by Andrews et al., 2012).
} 
broad evidence in Belfield and Bailey (2011). The lack of positive returns for certificates, mixed returns for diplomas, and strong returns for associate degrees correspond with results found in Kentucky by Jepsen et al. (2011); even as the specifications and samples differ somewhat, their estimates for the earnings gains from associate degrees are 54 percent for women and 22 percent for men. ${ }^{11}$

Table 2 shows how credit accumulation was associated with higher earnings nine years after students' initial enrollment. Students who accumulated more college-level credits had higher post-college earnings. In a linear model (column 1), each credit accumulated in community college was associated with earnings that were 0.7 percent higher for women and 0.4 percent higher for men. Each credit was associated with a quarterly earnings gain of \$29 and \$17 for women and men respectively. Thus, even as they accumulated more credits per award, female students reaped greater wage gains per credit on average. With inclusion of a quadratic term in the model (column 2), the earnings gains increased with each credit at a declining rate. However, the rate of decline was very slight: Only at very high credit levels would marginal credits reduce earnings gaps.

With credits expressed in bands of ten (column 3), there is evidence that even small numbers of credits are valuable; again, this finding is consistent with evidence presented by Belfield and Bailey (2011). Almost 13 percent of students in our sample accumulated zero collegelevel credits (either because they failed their first-semester courses or because they never progressed out of remediation); relative to these students, women who accumulated 1-10 credits earned \$638 more, and men who accumulated 1-10 credits earned \$1,162 more. In general, students continued to experience increases in earnings with each additional 10-credit increment. These results are based on credits accumulated only within the NCCCS, though many students gained credits at other colleges. Indeed, some students with less than 10 credits were transfer students who ultimately obtained a bachelor's degree. The NSC data do not include counts of credits for transfer students but do include information on durations in college and enrollment intensity within a term; we use this information to estimate the number of post-transfer credits (see notes to Table 2 for formula). In column 4 of Table 2, we include an estimate of credits accumulated after transfer to another college. ${ }^{12}$ There were positive returns to all amounts of credit accumulation, but the return directly attributable to NCCCS credits is approximately one third less than the estimate generated when we do not control for estimated credits after NCCCS. ${ }^{13}$

\footnotetext{
${ }^{11}$ Using data from the U.S. Census Bureau's American Community Survey, Zaback, Carlson, and Crellin (2012) reported a raw median earnings gain for associate degrees over high school graduation of 31 percent.

${ }^{12}$ Although the returns per credit appear lower for post-NCCCS credits than for NCCCS credits, we are reluctant to infer declining returns to higher education quality or credits (for a discussion, see Hilmer, 2000; Reynolds, 2012). Post-NCCCS credits are only approximated, and these are marginal credits beyond NCCCS credits and so may be subject to diminishing returns.

${ }^{13}$ The results in Table 2 show that the returns to college are not primarily sheepskin effects, although those with more than 51 credits experienced a larger gain. When we re-estimate Table 1 including the number of credits accumulated, we find that the coefficients on awards are not substantially lower (details available from the authors). This lack of effect also suggests positive sheepskin effects (Marcotte, 2010; Jepsen et al., 2011).
} 
Table 1: Returns to Awards: Average Quarterly Earnings Gains in 2011 for 2002-03 NCCCS Cohort

\begin{tabular}{|c|c|c|c|c|c|c|c|c|}
\hline & \multicolumn{4}{|c|}{ Women } & \multicolumn{4}{|c|}{ Men } \\
\hline & $(1)$ & (2) & (3) & (4) & (1) & $(2)$ & (3) & (4) \\
\hline \multicolumn{9}{|l|}{ Highest award attained } \\
\hline Certificate & $\begin{array}{r}-\$ 86 \\
{[89]}\end{array}$ & $\begin{array}{c}-\$ 336^{* * * *} \\
{[86]}\end{array}$ & $\begin{array}{c}-\$ 433^{* * * *} \\
{[87]}\end{array}$ & $\begin{array}{c}-\$ 347 * * * \\
{[87]}\end{array}$ & $\begin{array}{l}\$ 252^{* * *} \\
{[120]}\end{array}$ & $\begin{array}{l}-\$ 37 \\
{[112]}\end{array}$ & $\begin{array}{c}-\$ 342 * * * \\
{[114]}\end{array}$ & $\begin{array}{c}-\$ 279 * * \\
{[117]}\end{array}$ \\
\hline Diploma & $\begin{array}{c}\$ 1,574 * * * \\
{[110]}\end{array}$ & $\begin{array}{c}\$ 1,707 * * * \\
{[106]}\end{array}$ & $\begin{array}{c}\$ 1,629 * * * \\
{[107]}\end{array}$ & $\begin{array}{c}\$ 1,680 * * * \\
{[108]}\end{array}$ & $\begin{array}{c}\$ 55 \\
{[185]}\end{array}$ & $\begin{array}{r}-\$ 224 \\
{[182]}\end{array}$ & $\begin{array}{c}-\$ 600 * * * \\
{[182]}\end{array}$ & $\begin{array}{c}-\$ 545^{* * *} \\
{[184]}\end{array}$ \\
\hline Associate degree & $\begin{array}{c}\$ 2,135^{* * *} \\
{[58]}\end{array}$ & $\begin{array}{c}\$ 2,192 * * * \\
{[56]}\end{array}$ & $\begin{array}{c}\$ 2,074 * * * \\
{[57]}\end{array}$ & $\begin{array}{c}\$ 2,136^{* * *} \\
{[58]}\end{array}$ & $\begin{array}{c}\$ 1,692 * * * \\
{[101]}\end{array}$ & $\begin{array}{c}\$ 1,350 * * * \\
{[94]}\end{array}$ & $\begin{array}{c}\$ 1,005^{* * *} \\
{[97]}\end{array}$ & $\begin{array}{c}\$ 1,115^{* * *} \\
{[99]}\end{array}$ \\
\hline Bachelor's degree or higher & $\begin{array}{c}\$ 2,126^{* * *} \\
{[69]}\end{array}$ & $\begin{array}{c}\$ 2,469 * * * \\
{[68]}\end{array}$ & $\begin{array}{c}\$ 2,335^{* * *} \\
{[69]}\end{array}$ & $\begin{array}{c}\$ 2,284 * * * \\
{[70]}\end{array}$ & $\begin{array}{c}\$ 1,346^{* * *} \\
{[109]}\end{array}$ & $\begin{array}{c}\$ 1,996 * * * \\
{[104]}\end{array}$ & $\begin{array}{c}\$ 1,619^{* * *} \\
{[107]}\end{array}$ & $\begin{array}{c}\$ 1,588^{* * *} \\
{[109]}\end{array}$ \\
\hline \multicolumn{9}{|l|}{ Controls included in model } \\
\hline Background characteristics & & $\mathrm{X}$ & $\mathrm{X}$ & $\mathrm{X}$ & & $\mathrm{X}$ & $\mathrm{X}$ & $\mathrm{X}$ \\
\hline College & & $\mathrm{X}$ & $\mathrm{X}$ & $\mathrm{X}$ & & $\mathrm{X}$ & $\mathrm{X}$ & $\mathrm{X}$ \\
\hline Ability & & & $\mathrm{X}$ & $\mathrm{X}$ & & & $\mathrm{X}$ & $\mathrm{X}$ \\
\hline Intent/goal & & & & $\mathrm{X}$ & & & & $\mathrm{X}$ \\
\hline$R^{2}$ & 0.048 & 0.167 & 0.169 & 0.170 & 0.013 & 0.189 & 0.196 & 0.198 \\
\hline Observations & 49,187 & 49,187 & 49,187 & 49,187 & 31,384 & 31,384 & 31,384 & 31,384 \\
\hline
\end{tabular}

Note. Sample includes all first-time-in-college students who enrolled in an NCCCS college in 2002-03. Returns shown are based on the average of non-missing quarterly earnings in 2011 (adjusted for inflation to 2010 dollars). Comparison group is students who earned credits but received no award. Background characteristics include race/ethnicity (four dummy variables); single parenthood; high school graduation status; disability; years of work experience and square of years of work experience; enrollment status in 2011; age 18-19 at entry; expected family contribution (annual); and average per semester of grants, loans, and total financial aid. College variables are dummy variables for each NCCCS college. First-semester college GPA is used as a proxy for ability. Intent dummy variables include intent to earn an associate degree, intent to transfer to a four-year college, and intent to enroll in an occupational program (omitted: intent to earn a high school diploma). Goal dummy variables include goal of associate degree, goal of transfer to four-year college, and goal of enhancing job skills (omitted: goal of personal enrichment). Robust standard errors reported in brackets.

${ }^{*} p<.1 . * * p<.05 . * * * p<.01$. 
Table 2: Returns to Credits: Average Quarterly Earnings Gains in 2011 for 2002-03 NCCCS Cohort

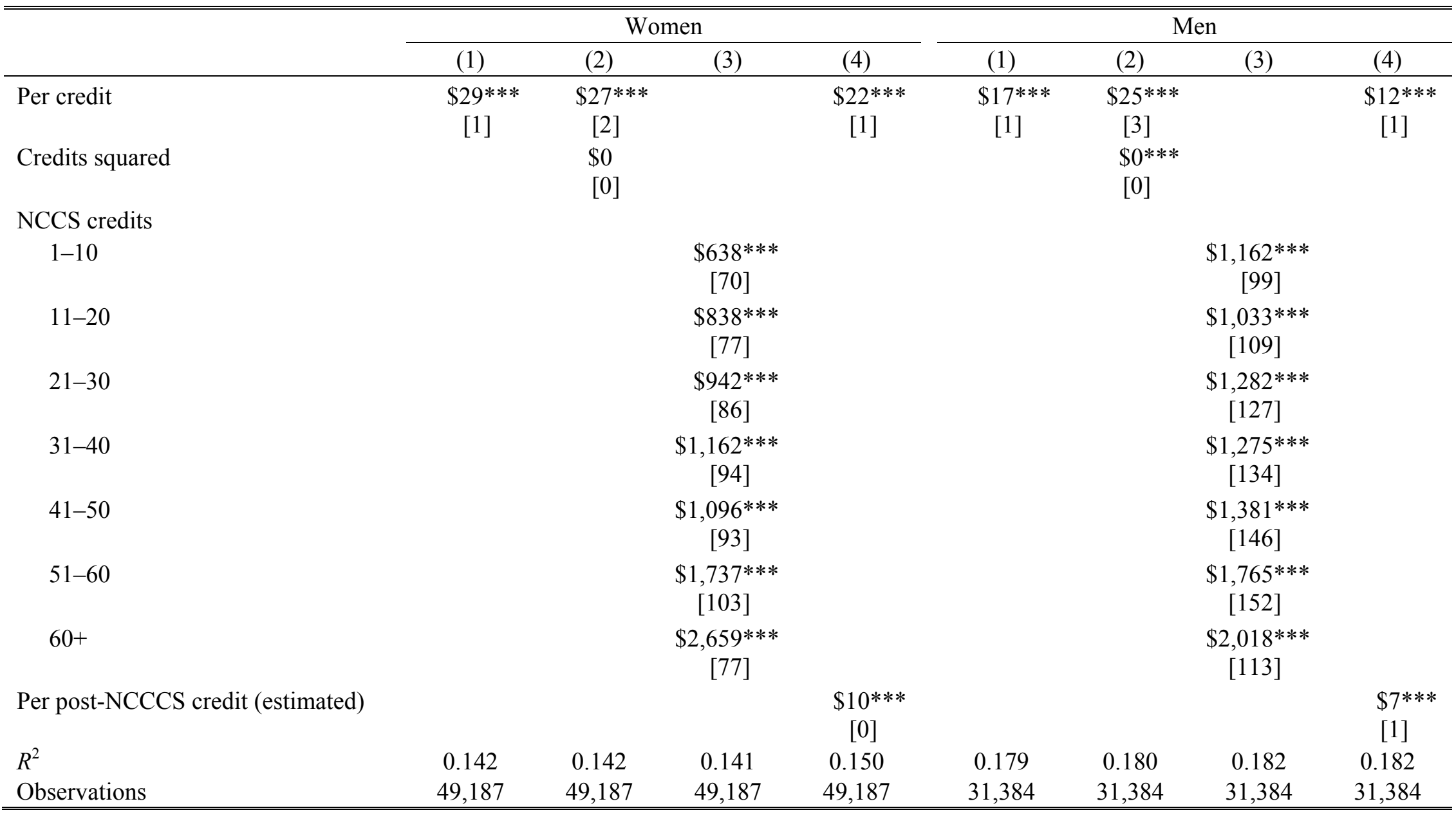

Note. Sample includes all first-time-in-college students who enrolled in an NCCCS college in 2002-03. Returns shown are based on the average of non-missing quarterly earnings in 2011 (adjusted for inflation to 2010 dollars). Comparison group is students who earned zero credits. Credits from non-NCCCS institutions are estimated using enrollment data from the National Student Clearinghouse. We estimate 12 credits per enrolled full-time term at a non-NCCCS school, 6 credits per half-time term, and 3 credits per less-than-half-time term. Specifications follow Table 1, Model 4. Model includes variables related to background characteristics, college, ability, and intent/goal. Robust standard errors reported in brackets.

${ }^{*} p<.1 . * * p<.05 . * * * p<.01$. 
In Table 3, we examine directly the effect of transfer on the returns to awards. For students who first enroll at a community college, there is mixed evidence on the labor market returns to transferring to another college. Students who complete a bachelor's degree earn more than all other groups (see Light \& Strayer, 2004; and Table 1 above). However, many transfer students in our sample did not obtain either an NCCCS award or a subsequent award. It is possible that these students would have experienced greater returns if they had continued until they completed their NCCCS program. Table 3 shows the effect of each NCCCS award and transfer in general, as well as the interaction between transfer and each award. The results for awards are similar to those displayed in Table 1: weak returns for certificates for all students and diplomas for men, and strong returns for associate degrees. Students who transferred did better than those who neither transferred nor earned a credential at the community college, with gains of $\$ 1,596$ for women and $\$ 725$ for men; some of these transfer students went on to earn a bachelor's degree. ${ }^{14}$ The interaction terms are negative, but the sizes of the effects are not sufficient to offset the awards or the effects of transfer. When students consider whether to earn an associate degree at their community college or to transfer out of the college, they should compare the gains of transferring without an associate degree, transferring with an associate degree, and earning an associate degree without transferring. For students in our sample, among these three options, transferring without an associate degree yielded the lowest gains in 2011 (\$1,596 for women and \$725 for men), and earning an associate degree with no transfer credits yielded the highest gains $(\$ 2,509$ for women and $\$ 1,308$ for men). Earning an associate degree and transferring yielded gains of $\$ 2,008$ for women and $\$ 944$ for men. These findings imply that on average, students who transfer would be better off earning an associate degree prior to transfer. However, for students who earn an associate degree there does not seem to be an additional benefit to transferring on average. ${ }^{15}$

In Table 4, we show earnings gains for award holders compared with non-awardees, split by award and subject. We find a mixed pattern of returns to awards for different subjects. The subject classifications are based on CIP codes and correspond to those in Dadgar and Weiss (2012). The returns from nursing and allied health qualifications are extremely high. Relative to female students who accumulated credits but did not earn an award, those with associate degrees and diplomas in nursing obtained earnings premiums of over 300 percent and 200 percent, respectively - or gains of $\$ 6,429$ and $\$ 3,724$ more per quarter. For women, only the subject of education/child care yielded no gain from an associate degree. Returns to diplomas for women were clustered in only a few subjects, and the only certificate with strong labor market value was in protective services. For men, gains patterns were even more varied. For certificates, the earnings penalties are spread across almost all subjects. For diplomas, there are few statistically significant

\footnotetext{
${ }^{14}$ As predicted by Jepsen et al. (2011), excluding transfer students from studies of labor market returns is therefore likely to result in a downward bias in estimates of the returns to an associate degree.

${ }^{15}$ Considering the fact that some students who transfer will end up earning a bachelor's degree and some will not — and Table 1 shows that students who earn a bachelor's degree do very well — this average may mask heterogeneous returns to transfers that depend upon success at the destination college. However, we do not model this tradeoff explicitly in this paper.
} 
results. Finally, the gains from associate degrees are concentrated in a few fields: nursing, allied health, construction, engineering, mechanics, and protective services. Indeed, this last field appears to be the only field with consistent gains across award types for males, although there were too few diploma earners to report. Also notable are the returns to associate degrees in construction; these remained high for men even after the Great Recession. Our results for health-related awards correspond with those of Jepsen et al. (2011) and Dadgar and Weiss (2012), but the general picture in Table 4 is heterogeneous. Some technical/vocational subjects had relatively low returns, and within-subject returns varied across awards. However, associate degrees broadly led to positive returns across most fields.

\section{Table 3: Returns to Transfer: Average Quarterly Earnings Gains in 2011 for 2002-03 NCCCS} Cohort

\begin{tabular}{lcc}
\hline \hline Award and Transfer Status & Women & Men \\
\hline Certificate & $-\$ 296^{* * *}$ & $-\$ 260^{* *}$ \\
& {$[91]$} & {$[122]$} \\
Certificate-transfer interaction & $-\$ 391$ & $-\$ 726^{* *}$ \\
& {$[304]$} & {$[370]$} \\
Diploma & $\$ 1,864 * * *$ & $-\$ 531 * * *$ \\
& {$[113]$} & {$[191]$} \\
Diploma-transfer interaction & $-\$ 1,441^{* * *}$ & $-\$ 666$ \\
& {$[369]$} & {$[683]$} \\
Associate degree & $\$ 2,509 * * *$ & $\$ 1,308^{* * *}$ \\
& {$[69]$} & {$[117]$} \\
Associate degree-transfer interaction & $-\$ 2,097 * * *$ & $-\$ 1,089 * * *$ \\
& {$[106]$} & {$[174]$} \\
Transfer & $\$ 1,596 * * *$ & $\$ 725^{* * *}$ \\
& {$[53]$} & {$[82]$} \\
$R^{2}$ & & 0.194 \\
Observations & 0.168 & 31,384 \\
\hline \hline
\end{tabular}

Note. Sample includes all first-time-in-college students who enrolled in an NCCCS college in 2002-03. Returns shown are based on the average of non-missing quarterly earnings in 2011 (adjusted for inflation to 2010 dollars). Specifications follow Table 1, Model 4. Model includes variables related to background characteristics, college, ability, and intent/goal. Transfer refers to any attendance at a four-year college recorded in National Student Clearinghouse dataset. Robust standard errors reported in brackets.

${ }^{*} p<.1 .{ }^{* *} p<.05 . * * * p<.01$. 
Table 4: Returns to Awards by Subject of Study: Average Quarterly Earnings Gains in 2011 for 2002-03 NCCCS Cohort

\begin{tabular}{|c|c|c|c|c|c|c|}
\hline \multirow[b]{2}{*}{ Subject } & \multicolumn{3}{|c|}{ Women } & \multicolumn{3}{|c|}{ Men } \\
\hline & Associate & Diploma & Certificate & Associate & Diploma & Certificate \\
\hline Nursing & $\begin{array}{c}\$ 6,429 * * * \\
{[131]}\end{array}$ & $\begin{array}{c}\$ 3,724 * * * \\
{[201]}\end{array}$ & $\begin{array}{l}-\$ 92 \\
{[335]}\end{array}$ & $\begin{array}{c}\$ 5,498 * * * \\
{[567]}\end{array}$ & $\begin{array}{l}\$ 1,894 \\
{[1,316]}\end{array}$ & \\
\hline Allied health & $\begin{array}{c}\$ 2,480 * * * \\
{[107]}\end{array}$ & $\begin{array}{c}\$ 1,400 * * * \\
{[136]}\end{array}$ & $\begin{array}{c}\$ 11 \\
{[189]}\end{array}$ & $\begin{array}{c}\$ 2,783 * * * \\
{[381]}\end{array}$ & $\begin{array}{r}-\$ 231 \\
{[650]}\end{array}$ & $\begin{array}{c}-\$ 2,581^{* *} \\
{[1,155]}\end{array}$ \\
\hline Transportation & & & $\begin{array}{c}-\$ 1,882^{* *} \\
{[820]}\end{array}$ & & & $\begin{array}{c}-\$ 1,278^{* * * *} \\
{[340]}\end{array}$ \\
\hline Other CTE/not assigned & $\begin{array}{c}\$ 1,606 * * * \\
{[284]}\end{array}$ & $\begin{array}{l}\$ 2,641 * \\
{[1,600]}\end{array}$ & $\begin{array}{l}\$ 381 \\
{[886]}\end{array}$ & $\begin{array}{l}\$ 729^{*} \\
{[401]}\end{array}$ & $\begin{array}{r}-\$ 1,241 \\
{[882]}\end{array}$ & $\begin{array}{c}-\$ 1,540^{* * * *} \\
{[427]}\end{array}$ \\
\hline Protective services & $\begin{array}{c}\$ 1,011 * * * \\
{[235]}\end{array}$ & & $\begin{array}{c}\$ 1,432 * * * \\
{[505]}\end{array}$ & $\begin{array}{c}\$ 2,176^{* * * *} \\
{[284]}\end{array}$ & & $\begin{array}{c}\$ 1,485^{* * *} \\
{[211]}\end{array}$ \\
\hline Engineering sciences & $\begin{array}{c}\$ 1,463 * * * \\
{[317]}\end{array}$ & & $\begin{array}{r}\$ 1,016 \\
{[882]}\end{array}$ & $\begin{array}{c}\$ 1,558^{* * * *} \\
{[231]}\end{array}$ & $\begin{array}{c}\$ 162 \\
{[1,132]}\end{array}$ & $\begin{array}{r}-\$ 409 \\
{[513]}\end{array}$ \\
\hline Information science, communication, design & $\begin{array}{c}\$ 1,205^{* * *} * \\
{[221]}\end{array}$ & & $\begin{array}{l}\$ 462 \\
{[831]}\end{array}$ & $\begin{array}{l}\$ 257 \\
{[266]}\end{array}$ & & $\begin{array}{l}\$ 677 \\
{[766]}\end{array}$ \\
\hline Business and marketing & $\begin{array}{l}\$ 967 * * * \\
{[122]}\end{array}$ & $\begin{array}{r}-\$ 687 \\
{[489]}\end{array}$ & $\begin{array}{c}\$ 83 \\
{[326]}\end{array}$ & $\begin{array}{l}\$ 221 \\
{[289]}\end{array}$ & & $\begin{array}{r}-\$ 658 \\
{[502]}\end{array}$ \\
\hline $\begin{array}{l}\text { Cosmetology, culinary, and administrative } \\
\text { services }\end{array}$ & $\begin{array}{l}\$ 781 * * * \\
{[227]}\end{array}$ & $\begin{array}{r}-\$ 118 \\
{[223]}\end{array}$ & $\begin{aligned} &-\$ 498 * * * \\
& {[190] }\end{aligned}$ & $\begin{array}{l}\$ 367 \\
{[550]}\end{array}$ & & $\begin{array}{c}-\$ 1,757 * * \\
{[789]}\end{array}$ \\
\hline Humanities and social sciences & $\begin{array}{l}\$ 451 * * * \\
{[110]}\end{array}$ & $\begin{array}{l}\$ 111 \\
{[575]}\end{array}$ & $\begin{array}{l}-\$ 691 \\
{[1,292]}\end{array}$ & $\begin{array}{c}\$ 46 \\
{[188]}\end{array}$ & & \\
\hline Education and childcare & $\begin{array}{l}-\$ 37 \\
{[110]}\end{array}$ & $\begin{array}{r}-\$ 128 \\
{[610]}\end{array}$ & $\begin{array}{c}-\$ 1,042 * * * \\
{[145]}\end{array}$ & $\begin{array}{r}-\$ 1,315 \\
{[969]}\end{array}$ & & \\
\hline Construction & & & & $\begin{array}{l}\$ 2,919 * * * \\
{[583]}\end{array}$ & $\begin{array}{c}-\$ 827 * * \\
{[402]}\end{array}$ & $\begin{array}{r}-\$ 706^{*} \\
{[390]}\end{array}$ \\
\hline Mechanics, repair, and welding & $\begin{array}{l}\$ 2,960 * * \\
{[1,231]}\end{array}$ & $\begin{array}{l}\$ 845 \\
{[801]}\end{array}$ & $\begin{array}{l}-\$ 180 \\
{[1,251]}\end{array}$ & $\begin{array}{l}\$ 1,668 * * * \\
{[301]}\end{array}$ & $\begin{array}{r}-\$ 363 \\
{[247]}\end{array}$ & $\begin{array}{c}-\$ 489 * * \\
{[237]}\end{array}$ \\
\hline$R^{2}$ & & 0.202 & & & 0.191 & \\
\hline Observations & & 49,187 & & & 31,384 & \\
\hline
\end{tabular}

Note. Sample includes all first-time-in-college students who enrolled in an NCCCS college in 2002-03. Returns shown are based on the average of non-missing quarterly earnings in given year (adjusted for inflation to 2010 dollars). Each cell is a coefficient by award by subject from a single equation. Specifications follow Model 4 of Table 1. Model includes variables related to background characteristics, college, ability, and intent/goal. Robust standard errors reported in brackets.

${ }^{*} p<.1 .{ }^{* *} p<.05 . * * p<.01$. 
Lastly, in Table 5, the labor market returns are split according to students' age on first enrollment. We divided the sample into students who were younger than age 20 when they first enrolled and those who were 20 or older. The returns to awards were mixed. For a few awards, gains were greater for students who entered college directly after high school; for other awards, those who entered college when they were older gained more. Students of all ages earned more if they obtained a degree, women gained more from earning a diploma, and there were weakly positive gains among male students who enrolled when they were under age 20 and obtained a certificate. Among students who earned a bachelor's degree or higher, the relative gain for older entrants $(\$ 1,719$ for younger women versus $\$ 2,879$ for older women; $\$ 1,473$ for younger men versus $\$ 2,140$ for older men) is statistically significant (interaction test, not reported). This finding contrasts with those of Jacobson et al. (2005), Jepsen et al. (2011), and Marcotte et al. (2005), who found more consistently that younger students benefitted more across award types.

Table 5: Returns to Awards by Age of Enrollment: Average Quarterly Earnings Gains in 2011 for 2002-03 NCCCS Cohort

\begin{tabular}{lccccc}
\hline \hline \multirow{2}{*}{ Award } & \multicolumn{2}{c}{ Women } & & \multicolumn{2}{c}{ Men } \\
\cline { 2 - 3 } \cline { 5 - 6 } Certificate & Age $<20$ & Age 20+ & & Age $<20$ & Age 20+ \\
\cline { 6 - 7 } Diploma & $-\$ 258^{*}$ & $-\$ 309 * * *$ & & $\$ 441^{* *}$ & $-\$ 227$ \\
& {$[139]$} & {$[108]$} & & {$[192]$} & {$[146]$} \\
Associate degree & $\$ 1,135^{* * *}$ & $\$ 1,940^{* * *}$ & & $\$ 421$ & $-\$ 947 * * *$ \\
& {$[144]$} & {$[150]$} & & {$[259]$} & {$[240]$} \\
Bachelor's degree or higher & $\$ 1,897^{* * *}$ & $\$ 2,202 * * *$ & & $\$ 991^{* * *}$ & $\$ 1,214 * * *$ \\
& {$[83]$} & {$[78]$} & & {$[119]$} & {$[155]$} \\
& $\$ 1,719^{* * *}$ & $\$ 2,879 * * *$ & & $\$ 1,473 * * *$ & $\$ 2,140 * * *$ \\
$R^{2}$ & {$[83]$} & {$[128]$} & & {$[117]$} & {$[225]$} \\
Observations & & & & \\
\hline \hline
\end{tabular}

Note. Sample includes all first-time-in-college students who enrolled in an NCCCS college in 2002-03. Returns shown are based on the average of non-missing quarterly earnings in 2011 (adjusted for inflation to 2010 dollars). Specifications follow Model 4 of Table 1. Model includes variables related to background characteristics, college, ability, and intent/goal. Robust standard errors reported in brackets.

$* p<.1 . * * p<.05 . * * * p<.01$. 


\section{The Trajectory of Labor Market Returns Over the Decade}

In this section, we examine the trajectory of labor market returns, estimating our preferred specification for time periods shorter than nine years after first enrollment. In a separate investigation, we look at the average returns over the entire period after exiting college. Lastly, we look at the returns to later cohorts using the preferred specification. We show how returns grew immediately after college, as well as the short-term impact of labor market changes during the 2000s.

Several factors may depress shorter term returns. For instance, students may not have completed their awards or found employment that matches their new skills. Alternately, their job tasks may not optimally apply their new skills. The longer the award requirements take to fulfill, the greater the expected depression is.

In Table 6, we compare the returns to awards at five, seven, and nine years after first enrollment (controls for experience are included in our preferred specification). The results indicate significant growth in returns to associate degree awards five and seven years after initial enrollment, compared with more moderate growth nine years afterward. Women who obtained certificates experienced progressively larger earnings penalties over time. For diplomas and degrees, women had strongly positive returns that increased over time. For men, the penalty for certificates and diplomas was consistent over time. On the other hand, for both women and men, the full impact of longer awards was not apparent after five years; the returns to these longer awards grew steadily over time. For associate degrees, the returns five years after initial enrollment were 42 percent for women and 22 percent for men ( $\$ 1,362$ and $\$ 486$ respectively); these were significant gains over students who did not complete an award, but they were lower than the returns after seven years $(\$ 1,905$ for women and $\$ 952$ for men) and approximately half the size of the returns after nine years $(\$ 2,136$ and $\$ 1,115$ respectively). This trend suggests the need for caution in interpreting even the nine-year window as sufficient to identify the full returns to associate degrees; long-term gains may exceed the medium-term gains for associate degree awardees reported here. This pattern is even clearer for bachelor's degree recipients. Five years after initial enrollment, the returns to bachelor's degrees were strongly negative for men and modestly positive for women; at seven years, there were statistically significant positive returns, with 49 percent gains for women and 21 percent gains for men. These gains substantially increased to 68 percent for women and 42 percent for men nine years after initial enrollment. Even as $\$ 1,588$ per quarter among men and $\$ 2,284$ per quarter among women represent significant gains, nine years after enrollment is most likely too early to estimate the full earnings gains from a four-year degree. 
Table 6: Returns to Awards by Duration After First Enrollment: Average Quarterly Earnings Gains for 2002-03 NCCCS Cohort

\begin{tabular}{|c|c|c|c|c|c|c|}
\hline \multirow[b]{2}{*}{ Award } & \multicolumn{3}{|c|}{ Women } & \multicolumn{3}{|c|}{ Men } \\
\hline & 2007 & 2009 & 2011 & 2007 & 2009 & 2011 \\
\hline Certificate & $\begin{array}{r}-\$ 35 \\
{[82]}\end{array}$ & $\begin{array}{c}-\$ 199^{* *} \\
{[85]}\end{array}$ & $\begin{array}{c}-\$ 347 * * * \\
{[87]}\end{array}$ & $\begin{array}{c}-\$ 286^{* * *} \\
{[109]}\end{array}$ & $\begin{array}{c}-\$ 368^{* * *} \\
{[114]}\end{array}$ & $\begin{array}{c}-\$ 279^{* *} \\
{[117]}\end{array}$ \\
\hline Diploma & $\begin{array}{c}\$ 1,215^{* * *} \\
{[91]}\end{array}$ & $\begin{array}{c}\$ 1,504 * * * \\
{[98]}\end{array}$ & $\begin{array}{c}\$ 1,680 * * * \\
{[108]}\end{array}$ & $\begin{array}{c}-\$ 436^{* * *} \\
{[166]}\end{array}$ & $\begin{array}{c}-\$ 650^{* * *} \\
{[173]}\end{array}$ & $\begin{array}{c}-\$ 545^{* * *} \\
{[184]}\end{array}$ \\
\hline Associate degree & $\begin{array}{c}\$ 1,362 * * * \\
{[53]}\end{array}$ & $\begin{array}{c}\$ 1,905 * * * \\
{[57]}\end{array}$ & $\begin{array}{c}\$ 2,136^{* * * *} \\
{[58]}\end{array}$ & $\begin{array}{c}\$ 486 * * * \\
{[84]}\end{array}$ & $\begin{array}{c}\$ 952 * * * \\
{[93]}\end{array}$ & $\begin{array}{c}\$ 1,115^{* * * *} \\
{[99]}\end{array}$ \\
\hline $\begin{array}{l}\text { Bachelor's degree or } \\
\text { higher }\end{array}$ & $\begin{array}{l}\$ 320 * * * \\
{[58]}\end{array}$ & $\begin{array}{c}\$ 1,594 * * * \\
{[67]}\end{array}$ & $\begin{array}{c}\$ 2,284 * * * \\
{[70]}\end{array}$ & $\begin{array}{c}-\$ 993 * * * \\
{[80]}\end{array}$ & $\begin{array}{l}\$ 521 * * * \\
{[96]}\end{array}$ & $\begin{array}{c}\$ 1,588 * * * \\
{[109]}\end{array}$ \\
\hline$R^{2}$ & 0.195 & 0.167 & 0.170 & 0.278 & 0.209 & 0.198 \\
\hline Observations & 49,187 & 49,186 & 49,187 & 31,382 & 31,383 & 31,384 \\
\hline
\end{tabular}

Note. Sample includes all first-time-in-college students who enrolled in an NCCCS college in 2002-03. Returns shown are based on the average of non-missing quarterly earnings in given year (adjusted for inflation to 2010 dollars). Specifications follow Model 4 of Table 1. Model includes variables related to background characteristics, college, ability, and intent/goal. Robust standard errors reported in brackets.

${ }^{*} p<.1 .{ }^{* *} p<.05 . * * * p<.01$.

We also apply an alternative approach to identifying returns over the early post-college years. Instead of looking at a snapshot of earnings differences nine years after first enrollment, we look at average quarterly gains for different student subgroups, from the first quarter after graduation until the end of the tracking period, nine years after students' first enrollment. We estimate a model with all observations in each quarter for which an individual has earnings, including quarters before the student enrolled in college. Students are assigned awards in the quarter after they graduate with that award and in all succeeding quarters; if a student then obtains a higher award (e.g., an associate degree after a certificate), the earlier award (certificate) is set to zero in that quarter. We include an indicator for when a student was enrolled in college, so we can see how enrollment adversely affected earnings. We also include a fixed effect for each student to control for time-invariant student characteristics (see similar models by Dadgar \& Weiss, 2012; Jepsen et al., 2012).

The results for this specification are given in Table 7. These results are for three cohorts of students (those who first enrolled in college in the academic years from 2002-03 to 2004-05) and represent earnings gains for all quarters up to nine years after first enrollment. The advantages of this specification are that it uses more information on earnings and that it controls for time-invariant student characteristics. The disadvantage is that each coefficient must be 
interpreted precisely and understood in light of the many student pathways available. In Table 7, the coefficients on awards are based on the highest award in a particular quarter.

Table 7 shows strong gains from degrees. In each quarter after completing an associate degree, earnings were $\$ 1,907$ or $\$ 1,133$ higher for women and men, respectively. In each quarter after receiving a bachelor's degree, earnings were $\$ 3,292$ higher for women and $\$ 3,002$ higher for men. These differences - though based on a shorter time frame - are similar to those reported in Table 1. However, the fixed effects model shows strong labor market gains for both certificates and diplomas for both men and women. In the quarters after earning a diploma, there were earnings gains of $\$ 1,565$ for women and $\$ 564$ for men. For certificates, the gains were small but statistically significant at $\$ 157$ and $\$ 476$, respectively. These results, which contrast with those in Table 1, may mean that certificates and diplomas generated earnings gains that were only temporary. Finally, Table 7 also shows the effect on earnings of being enrolled in college (either an NCCCS college or a transfer college), which can be thought of as the opportunity cost of college enrollment. For each quarter a student was enrolled, their earnings were approximately $\$ 310-\$ 580$ lower. This enrollment penalty is statistically significant but small when compared with the earnings gains for each quarter after graduation. 


\begin{tabular}{|c|c|c|}
\hline & Women & Men \\
\hline \multicolumn{3}{|l|}{ Award } \\
\hline Certificate & $\begin{array}{r}\$ 157 * * * \\
{[36.47]}\end{array}$ & $\begin{array}{r}\$ 476 * * * \\
{[54.54]}\end{array}$ \\
\hline Diploma & $\begin{array}{r}\$ 1,565 * * * \\
{[50.05]}\end{array}$ & $\begin{array}{r}\$ 564 * * * \\
{[85.91]}\end{array}$ \\
\hline Associate degree & $\begin{array}{r}\$ 1,907 * * * \\
{[30.28]}\end{array}$ & $\begin{array}{r}\$ 1,133 * * * \\
{[43.44]}\end{array}$ \\
\hline Bachelor's degree or higher & $\begin{array}{r}\$ 3,292 * * * \\
{[36.30]}\end{array}$ & $\begin{array}{r}\$ 3,002 * * * \\
{[53.08]}\end{array}$ \\
\hline \multicolumn{3}{|l|}{ College enrollment } \\
\hline Post-NCCCS college & $\begin{array}{r}-\$ 373.3 * * * \\
{[5.969]}\end{array}$ & $\begin{array}{r}-\$ 580.5 * * * \\
{[9.277]}\end{array}$ \\
\hline NCCCS college & $\begin{array}{r}-\$ 306.5 * * * \\
{[6.771]}\end{array}$ & $\begin{array}{c}-\$ 358.1 * * * \\
{[10.51]}\end{array}$ \\
\hline Ashenfelter dip & $\begin{array}{r}-\$ 136.2 * * * \\
{[6.837]}\end{array}$ & $\begin{array}{c}-\$ 239.4 * * * \\
{[11.48]}\end{array}$ \\
\hline Black * quarter & $\begin{array}{c}-16.28 * * * \\
{[0.858]}\end{array}$ & $\begin{array}{c}-21.28^{* * *} \\
{[1.467]}\end{array}$ \\
\hline Hispanic * quarter & $\begin{array}{l}-8.748 * * * \\
{[2.817]}\end{array}$ & $\begin{array}{c}-14.27 * * * \\
{[4.235]}\end{array}$ \\
\hline Other race $*$ quarter & $\begin{array}{l}-7.343 * * * \\
{[2.013]}\end{array}$ & $\begin{array}{c}-10.10^{* * *} \\
{[2.900]}\end{array}$ \\
\hline Age over $25 *$ quarter & $\begin{array}{c}-80.98 * * * \\
{[0.829]}\end{array}$ & $\begin{array}{r}-106.9 * * * \\
{[1.387]}\end{array}$ \\
\hline Quarter & $\begin{array}{r}100.1 * * * \\
{[2.547]}\end{array}$ & $\begin{array}{r}203.5^{* * *} \\
{[4.068]}\end{array}$ \\
\hline Quarter squared & $\begin{array}{c}0.0240 \\
{[0.0293]}\end{array}$ & $\begin{array}{c}-0.894 * * * \\
{[0.0472]}\end{array}$ \\
\hline$R^{2}$ & 0.189 & 0.158 \\
\hline Quarterly earnings observations & $3,255,979$ & $1,992,497$ \\
\hline Personal observations & 141,683 & 93,430 \\
\hline
\end{tabular}

Note. Sample includes all first-time-in-college students who enrolled in an NCCCS college in the academic years from 2002-03 to 2004-05. Award status identified for each quarter award is held. Ashenfelter dip is defined as average quarterly earnings in four quarters before enrollment in an NCCCS college. Quarter is calendar quarter (e.g., 2002 Q3). Constant term included. Robust standard errors reported in brackets.

$* p<.1 . * * p<.05 . * * * p<.01$. 
In Figure 1, we show the five-year earnings gains for selected awards for each of the entry cohorts from 2001-02 to 2007-08. ${ }^{16}$ Overall, the figure shows how earnings gains changed over the decade and the impact of the weak labor market in the late 2000s. ${ }^{17}$ The earlier cohorts (2001-02 and 2002-03) entered a relatively strong labor market (2003-06); the later cohorts (2003-04 to 2005-06) sought college-level jobs during the slump years of the Great Recession (December 2007-June 2009). Of course, the economic slump affected all workers, and students who did not complete an award may have suffered disproportionately. These non-awardees (who accumulated fewer credits) entered the labor market earlier than award holders, creating a potential wedge in the effect of the Great Recession on non-awardees versus awardees. However, Figure 1 shows no strong disparate impact across awards in the 2000s. Although there are some differences in returns year-on-year, there is no discernible trend or kink after the start of the Great Recession. Certainly, there is no obvious relative penalty for the later cohorts of students who left college with their awards during the Great Recession.

\section{Figure 1: Average Quarterly Earnings Gains Five Years After Enrollment by Cohort}

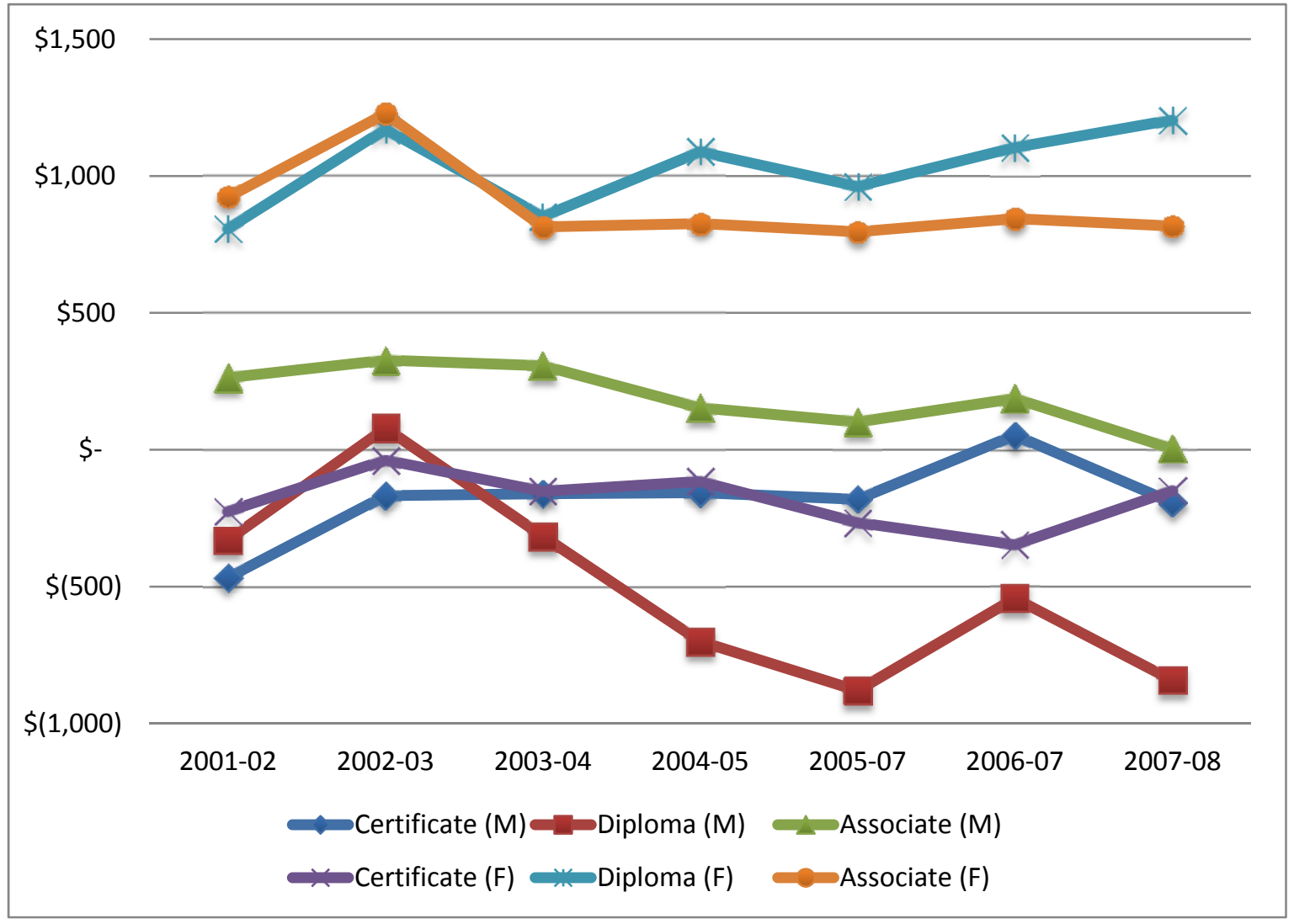

${ }^{16}$ As we are restricted to using a five-year lag, we do not report the gains for bachelor's degrees. The gains for certificates for women and for diplomas for men rarely obtain statistical significance. We include the 2001-02 cohort, although the sample available to us for this cohort does not include the full NCCCS enrollment.

${ }^{17}$ These results are illustrative because we have not accounted for date of entry into the labor market, which is likely to be endogenous to economic conditions. 


\section{Employment Effects of Awards}

Community college is likely to have dual effects-increasing employment probabilities as well as raising earnings. In Table 8 , we show the association between award status for the 2002-03 cohort and having no reported earnings - that is, being unemployed or otherwise not in the North Carolina labor market — nine years after first enrollment. We assign a binary indicator to all persons with no reported earnings in North Carolina in any quarter of 2011. Award receipt had a strong negative association with unemployment, with particularly strong effects for degree holders and female diploma awardees. Compounding the earnings effects reported in Table 1, the effect of an award on employment is greater for women than for men. ${ }^{18}$

\section{Table 8: Probability of Unemployment by Award Status in 2011 for 2002-03 NCCCS Cohort}

\begin{tabular}{lcc}
\hline \hline Award & Women & Men \\
\hline Certificate & 0.016 & -0.001 \\
& {$[0.010]$} & {$[0.010]$} \\
Diploma & $-0.063^{* * *}$ & 0.016 \\
& {$[0.010]$} & {$[0.016]$} \\
Associate degree & $-0.067^{* * *}$ & $-0.043^{* * *}$ \\
& {$[0.005]$} & {$[0.007]$} \\
Bachelor's degree or higher & $-0.079^{* * *}$ & $-0.047^{* * *}$ \\
& {$[0.006]$} & {$[0.008]$} \\
$R^{2}$ & & 0.091 \\
Observations & 0.082 & 31,384 \\
\hline \hline
\end{tabular}

Note. Sample includes all first-time-in-college students who enrolled in an NCCCS college in 2002-03. Dependent variable equals 1 if person had no reported earnings in any quarter of 2011. Specifications follow Model 4 of Table 1. Model includes variables related to background characteristics, college, ability, and intent/goal. Robust standard errors reported in brackets.

$* p<.1 . * * p<.05 . * * * p<.01$.

\footnotetext{
${ }^{18}$ Using the two-stage least squares method, we investigated the impact of adjusting for employment on the returns to awards reported in Table 1 . The coefficients in Table 1 were not substantially altered by the two-stage estimation.
} 


\section{Discussion and Conclusion}

Recent changes in the labor market and higher education have raised the stakes on making the right investments in college. Increasingly, students are following highly differentiated pathways through college, and thus they need timely and specific information about the economic value of their chosen pathway. This information can best be obtained through the analysis of large datasets of student transcripts matched to earnings.

Increasingly, administrative data are being used to report unadjusted wages for graduates from each United States college, with the goal of helping students make more informed choices (e.g., Schneider \& Vivari, 2012; Zaback et al., 2012). The validity of these reports is not especially contingent on the fact that they report unadjusted earnings. However, their results are often based on small samples and use early snapshot data that are most likely premature in identifying earnings gains. Moreover, community college students follow many pathways, and institutional choices may be less important than award completion, subject of study, credit accumulation, transfer, and progression to a bachelor's degree program.

The evidence from North Carolina emphasizes the heterogeneity of students' college trajectories and complements recent evidence from Kentucky, Washington State, and Texas. Evidence from the latter three states indicates returns almost as strong - and as mixed - as we found in North Carolina. Relative to students who do not obtain an award, students who earn certificates and diplomas may have an advantage in the labor market, but the gains of individuals with these credentials are sensitive to how earnings are modeled and the time frame of the data examined. Nonetheless, certificates and diplomas appear beneficial if they are in particular subjects, especially in health fields or protective services. The returns to associate degrees are very strong across almost all fields, especially for women. Community college students who transfer and complete a bachelor's degree also have high returns, although the majority of their credits are acquired at the four-year institution. We also found strong evidence that all credit accumulation is valuable, even for students who do not complete an award, although the returns to completing an award appear to exceed those from an equivalent number of credits. This finding is important, given that students tend to accumulate more credits than are required for their awards. Transferring to another college appears beneficial on average, but the highest returns accrue to students who earn an associate degree regardless of whether they transfer or not.

Our analysis shows that students' earnings grew rapidly in the years immediately after college, and even nine years after initial enrollment, the returns to associate degrees and bachelor's degrees were still increasing. Over the early trajectory of earnings for these cohorts, returns to these awards increased annually, such that our estimates likely understate the value of community college awards. Using a fixed effects specification affirmed or even strengthened our findings. The returns to awards were modestly lower for students who graduated during the Great Recession, but this diminution appears to have been temporary; the returns for cohorts that 
entered college at the start of the Great Recession are similar to those for cohorts that entered the labor market before the recession began.

From the student perspective, the completion of an associate degree appears to be a very high-yielding investment. Even over the nine-year period after first enrollment, the internal rate of return (labor market gains net of tuition costs and forgone income) to an associate degree, compared with no award, is approximately 16 percent for women and 5 percent for men. ${ }^{19}$ These rates exclude any wage gains made more than nine years after graduation, as well as the option value of transferring to obtain a bachelor's degree and the reduction in risk of job loss in a weak labor market.

Our evidence on the heterogeneity of returns to community college suggests the need for further inquiry into the consequences of students' enrollment choices. Of particular interest are the returns to college quality, to remedial coursework, and to particular clusters of coursework for those who do not complete an award. The labor market consequences of different transfer patterns also merit attention, especially as more students are enrolling at for-profit colleges to augment their human capital. Further investigation of the effects of selection bias and omitted variable bias for each of these pathways is also necessary.

\footnotetext{
${ }^{19}$ This internal rate of return calculation assumes tuition costs of $\$ 69$ per NCCCS credit. Full details are available from the authors.
} 


\section{References}

Altonji, J. G., Blom, E., \& Meghir, C. (2012). Human capital investments: High school curriculum, college major, and careers. Annual Review of Economics, 4(1), 185-223.

Andrews, R. J., Li, J., \& Lovenheim, M. F. (2012). Quantile treatment effects of college quality on earnings: Evidence from administrative data in Texas (NBER Working Paper No. 18068). Cambridge, MA: National Bureau of Economic Research. Retrieved from www.nber.org/papers/w18068

Arcidiacono, P. (2004). Ability sorting and the returns to college major. Journal of Econometrics, 121(1-2), 343-375.

Babcock, P., \& Marks, M. (2011). The falling time cost of college: Evidence from half a century of time use data. Review of Economics and Statistics, 93(2), 468-478.

Bailey, T. (2012). Can community colleges achieve ambitious graduation goals? In A. P. Kelly \& M. Schneider (Eds.), Getting to graduation: The completion agenda in higher education (pp. 73-101). Baltimore, MD: Johns Hopkins University Press.

Bailey, T., \& Belfield, C. R. (2012). Community college occupational degrees: Are they worth it? In L. Perna (Ed.), Preparing today's students for tomorrow's jobs in metropolitan America. Philadelphia, PA: University of Pennsylvania Press.

Bailey, T., Jeong, D. W., \& Cho, S. W. (2010). Referral, enrollment and completion in developmental education sequences in community colleges. Economics of Education Review, 29(2), 255-270.

Belfield, C. R., \& Bailey, T. (2011). The benefits of attending community college: A review of the evidence. Community College Review, 39(1), 46-68.

Black, D. A., Kolesnikova, N., \& Taylor, L. (2009). Earnings functions when wages and prices vary by location. Journal of Labor Economics, 27(1), 21-47.

Bollinger, C. R., \& Hirsch, B. T. (2006). Match bias from earnings imputation in the Current Population Survey: The case of imperfect matching. Journal of Labor Economics, 24(3), 483-520.

Bound, J., Lovenheim, M. F., \& Turner, S. (2010). Why have college completion rates declined? An analysis of changing student preparation and collegiate resources. American Economic Journal: Applied Economics, 2(3), 129-157.

Brand, J. E., \& Xie, Y. (2010). Who benefits most from college? Evidence for negative selection in heterogeneous economic returns to higher education. American Sociological Review, 75(2), 273-302. 
Carneiro, P., Heckman, J. J., \& Vytlacil, E. J. (2011). Estimating marginal returns to education. American Economic Review, 101(6), 2754-2781.

Carnevale, A. P., Jayasundera, T., \& Cheah, B. (2012). The college advantage: Weathering the economic storm. Washington, DC: Georgetown University, Center on Education and the Workforce. Retrieved from http://cew.georgetown.edu/collegeadvantage/

Carnevale, A. P., Smith, N., \& Strohl, J. (2009). Help wanted: Projections of jobs and education requirements through 2018. Washington, DC: Georgetown University, Center on Education and the Workforce.

Cyrenne, P., \& Chan, A. (2012). High school grades and university performance: A case study. Economics of Education Review, 31(5), 524-542.

Dadgar, M., \& Weiss, M. J. (2012). Labor market returns to sub-baccalaureate credentials: How much does a community college degree or certificate pay? (CCRC Working Paper No. 45). New York, NY: Columbia University, Teachers College, Community College Research Center.

Davis, S. J., \& von Wachter, T. (2011). Recessions and the costs of job loss. Brookings Papers on Economic Activity, 43(2), 1-72.

Flores-Lagunes, A., \& Light, A. (2010). Interpreting degree effects in the returns to education. Journal of Human Resources, 45(2), 439-467.

Goldin, C., \& Katz, L. F. (2008). The race between education and technology. Cambridge, MA: Belknap Press of Harvard University.

Henderson, D. J., Polachek, S. W., \& Wang, L. (2011). Heterogeneity in schooling rates of return. Economics of Education Review, 30(6), 1202-1214.

Hilmer, M. J. (2000). Does the return to university quality differ for transfer students and direct attendees? Economics of Education Review, 19(1), 47-61.

Horn, L., \& Nevill, S. (2006). Profile of undergraduates in U.S. postsecondary education institutions: 2003-04, With a special analysis of community college students (NCES 2006-184). Washington, DC: U.S. Department of Education, Institute of Education Sciences, National Center for Education Statistics.

Hossler, D., Shapiro, D., Dundar, A., Chen, J., Zerquera, D., Ziskin, M., \& Torres, V. (2012). Reverse transfer: A national view of student mobility from four-year to two-year institutions (Signature Report No. 3). Herndon, VA: National Student Clearinghouse Research Center. Retrieved from http://www.studentclearinghouse.info/signature/3/NSC_Signature_Report 3.pdf

Jacobson, L., LaLonde, R., \& Sullivan, D. G. (2005). Estimating the returns to community college schooling for displaced workers. Journal of Econometrics, 125(1-2), 271-304. 
Jepsen, C., Troske, K., \& Coomes, P. (2011). The labor market returns to community college degrees, diplomas and certificates (Discussion Paper Series No. DP 2009-08). Lexington, KY: University of Kentucky, Center for Poverty Research. Retrieved from http://www.ukcpr.org/Publications/DP2009-08.pdf

Kahn, L. B. (2009). The long-term labor market consequences of graduating from college in a bad economy. Unpublished manuscript, Yale School of Management, New Haven, CT.

Kaymak, B. (2009). Ability bias and the rising education premium in the United States: A cohort-based analysis. Journal of Human Capital, 3(3), 224-267.

Kinsler J., \& Pavan, R. (2011). Family income and higher education choices: The importance of accounting for college quality. Journal of Human Capital, 5(4), 453-477.

Light, A., \& Strayer, W. (2004). Who receives the college wage premium? Assessing the labor market returns to degrees and other college transfer patterns. Journal of Human Resources, 39(3), 746-773.

Lovenheim, M. F., \& Reynolds, C. L. (2011). Changes in postsecondary choices by ability and income: Evidence from the National Longitudinal Surveys of Youth. Journal of Human Capital, 5(1), 70-109.

Marcotte, D. E. (2010). The earnings effect of education at community colleges. Contemporary Economic Policy, 28(1), 36-51.

Marcotte, D. E., Bailey, T., Borkoski, C., \& Kienzl, G. S. (2005). The returns of a community college education: Evidence from the National Education Longitudinal Survey. Educational Evaluation and Policy Analysis, 27(2), 157-175.

Mulligan, C. B. (2012). The redistribution recession: How labor market distortions contracted the economy. New York, NY: Oxford University Press.

North Carolina Community College System. (2007). A matter of facts: The North Carolina Community College System fact book. Raleigh, NC: Author. Retrieved from http://www.nccommunitycolleges.edu/Publications/docs/Publications/fb2007.pdf

Reynolds, C. L. (2012). Where to attend? Estimating the effects of beginning college at a twoyear institution. Economics of Education Review, 31(4), 345-362.

Romano, R. M., Losinger, R., \& Millard, T. (2011). Measuring the cost of a college degree: A case study of a SUNY community college. Community College Review, 39(3), 211-234.

Schmitt, J., \& Baker, D. (2006). The impact of undercounting in the Current Population Survey. Washington, DC: Center for Economic Policy and Research.

Schneider, M., \& Vivari, B. (2012). The earning power of graduates from Tennessee's colleges and universities: How are graduates from different degree programs doing in the labor market? Washington, DC: American Institutes for Research. 
Shapiro, D., Dundar, A., Chen, J., Ziskin, M., Park, E., Torres, V., \& Chiang, Y.-C. (2013). Completing college: A national view of student attainment rates (Signature Report No. 4). Herndon, VA: National Student Clearinghouse Research Center.

Snyder, T. D., \& Dillow, S. A. (2012). Digest of education statistics 2011 (NCES 2012-001). Washington, DC: U.S. Department of Education, Institute of Education Sciences, National Center for Education Statistics.

Stange, K. M. (2012). An empirical investigation of the option value of college enrollment. American Economic Journal: Applied Economics, 4(1), 49-84.

Stevens, D. W. (2007). Employment that is not covered by state unemployment insurance laws (Technical Paper No. TP-2007-04). Suitland, MD: U.S. Census Bureau, Longitudinal Employer-Household Dynamics Program.

Zaback, K., Carlson, A., \& Crellin, M. (2012). The economic benefit of postsecondary degrees. A state and national level analysis. Boulder, CO: State Higher Education Executive Officers. 


\section{Appendix}

Appendix Table 1: Descriptive Frequencies for 2002-03 NCCCS Cohort by Highest Award Earned

\begin{tabular}{|c|c|c|c|c|c|c|c|c|c|c|}
\hline & \multicolumn{5}{|c|}{ Women } & \multicolumn{5}{|c|}{ Men } \\
\hline & $\begin{array}{c}\text { No } \\
\text { Award }\end{array}$ & Certificate & Diploma & $\begin{array}{c}\text { Associate } \\
\text { Degree }\end{array}$ & $\begin{array}{c}\text { Bachelor's } \\
\text { Degree + }\end{array}$ & $\begin{array}{c}\text { No } \\
\text { Award }\end{array}$ & Certificate & Diploma & $\begin{array}{c}\text { Associate } \\
\text { Degree }\end{array}$ & $\begin{array}{c}\text { Bachelor's } \\
\text { Degree + } \\
\end{array}$ \\
\hline \multicolumn{11}{|c|}{ Quarterly earnings in 2011} \\
\hline$M$ & $\$ 5,190$ & $\$ 5,012$ & $\$ 6,603$ & $\$ 7,232$ & $\$ 7,634$ & $\$ 6,909$ & $\$ 7,191$ & $\$ 6,988$ & $\$ 8,326$ & $\$ 8,529$ \\
\hline$S D$ & $\$ 3,982$ & $\$ 3,461$ & $\$ 3,767$ & $\$ 4,326$ & $\$ 4,777$ & $\$ 5,457$ & $\$ 4,603$ & $\$ 4,517$ & $\$ 5,072$ & $\$ 6,063$ \\
\hline Missing & 7,577 & 430 & 259 & 1,325 & 1,359 & 5,260 & 482 & 187 & 627 & 920 \\
\hline NCCCS credits & 21.2 & 37.6 & 65.3 & 81.1 & 30.9 & 19.9 & 29.1 & 55.8 & 76.6 & 33.2 \\
\hline \multicolumn{11}{|l|}{ Race/ethnicity } \\
\hline Black & $33 \%$ & $31 \%$ & $21 \%$ & $22 \%$ & $20 \%$ & $25 \%$ & $28 \%$ & $23 \%$ & $12 \%$ & $11 \%$ \\
\hline Hispanic & $2 \%$ & $2 \%$ & $1 \%$ & $2 \%$ & $2 \%$ & $2 \%$ & $2 \%$ & $2 \%$ & $2 \%$ & $2 \%$ \\
\hline White & $60 \%$ & $62 \%$ & $73 \%$ & $72 \%$ & $73 \%$ & $68 \%$ & $67 \%$ & $69 \%$ & $81 \%$ & $81 \%$ \\
\hline Other & $5 \%$ & $5 \%$ & $5 \%$ & $4 \%$ & $6 \%$ & $5 \%$ & $3 \%$ & $6 \%$ & $5 \%$ & $6 \%$ \\
\hline High school graduate & $83 \%$ & $90 \%$ & $87 \%$ & $88 \%$ & $63 \%$ & $76 \%$ & $85 \%$ & $88 \%$ & $86 \%$ & $62 \%$ \\
\hline Years worked & 14.5 & 17.7 & 13.3 & 13.6 & 8.3 & 11.4 & 14.8 & 14.4 & 11.6 & 6.9 \\
\hline Still enrolled in 2010 & $10 \%$ & $18 \%$ & $17 \%$ & $17 \%$ & $3 \%$ & $6 \%$ & $9 \%$ & $10 \%$ & $15 \%$ & $2 \%$ \\
\hline Age $18-19$ at entry & $22 \%$ & $16 \%$ & $26 \%$ & $26 \%$ & $32 \%$ & $31 \%$ & $15 \%$ & $26 \%$ & $36 \%$ & $36 \%$ \\
\hline \multicolumn{11}{|l|}{ Financial aid } \\
\hline EFC per semester & $\$ 4,350$ & $\$ 5,081$ & $\$ 6,777$ & $\$ 6,246$ & $\$ 1,852$ & $\$ 2,436$ & $\$ 2,009$ & $\$ 3,182$ & $\$ 3,990$ & $\$ 1,485$ \\
\hline Total grants & $\$ 2,044$ & $\$ 2,815$ & $\$ 4,777$ & $\$ 5,152$ & $\$ 1,123$ & $\$ 942$ & $\$ 919$ & $\$ 1,904$ & $\$ 2,527$ & $\$ 730$ \\
\hline Total college loans & $\$ 178$ & $\$ 254$ & $\$ 475$ & $\$ 665$ & $\$ 167$ & $\$ 115$ & $\$ 92$ & $\$ 142$ & $\$ 396$ & $\$ 126$ \\
\hline Total financial aid & $\$ 2,297$ & $\$ 3,252$ & $\$ 5,552$ & $\$ 6,339$ & $\$ 1,366$ & $\$ 1,141$ & $\$ 1,136$ & $\$ 2,413$ & $\$ 3,373$ & $\$ 975$ \\
\hline
\end{tabular}




\begin{tabular}{|c|c|c|c|c|c|c|c|c|c|c|}
\hline & \multicolumn{5}{|c|}{ Women } & \multicolumn{5}{|c|}{ Men } \\
\hline & $\begin{array}{c}\text { No } \\
\text { Award }\end{array}$ & Certificate & Diploma & $\begin{array}{l}\text { Associate } \\
\text { Degree }\end{array}$ & $\begin{array}{c}\text { Bachelor's } \\
\text { Degree + }\end{array}$ & $\begin{array}{c}\text { No } \\
\text { Award }\end{array}$ & Certificate & Diploma & $\begin{array}{l}\text { Associate } \\
\text { Degree }\end{array}$ & $\begin{array}{c}\text { Bachelor's } \\
\text { Degree + }\end{array}$ \\
\hline First-semester college GPA & 2.46 & 3.05 & 2.91 & 3.09 & 3.12 & 2.19 & 2.95 & 3.14 & 3.03 & 2.96 \\
\hline \multicolumn{11}{|l|}{ Intent } \\
\hline Associate degree & $16 \%$ & $13 \%$ & $29 \%$ & $21 \%$ & $7 \%$ & $5 \%$ & $2 \%$ & $5 \%$ & $9 \%$ & $3 \%$ \\
\hline Transfer to four-year & $25 \%$ & $15 \%$ & $24 \%$ & $38 \%$ & $37 \%$ & $30 \%$ & $10 \%$ & $13 \%$ & $40 \%$ & $44 \%$ \\
\hline Occupation study & $55 \%$ & $95 \%$ & $98 \%$ & $87 \%$ & $20 \%$ & $50 \%$ & $96 \%$ & $98 \%$ & $81 \%$ & $18 \%$ \\
\hline High school diploma & $14 \%$ & $8 \%$ & $11 \%$ & $11 \%$ & $34 \%$ & $20 \%$ & $8 \%$ & $10 \%$ & $12 \%$ & $35 \%$ \\
\hline \multicolumn{11}{|l|}{ Goal } \\
\hline Associate degree & $27 \%$ & $37 \%$ & $45 \%$ & $45 \%$ & $15 \%$ & $21 \%$ & $23 \%$ & $27 \%$ & $40 \%$ & $15 \%$ \\
\hline Transfer & $7 \%$ & $4 \%$ & $7 \%$ & $12 \%$ & $16 \%$ & $8 \%$ & $3 \%$ & $3 \%$ & $13 \%$ & $18 \%$ \\
\hline Enhance job skills & $4 \%$ & $6 \%$ & $5 \%$ & $4 \%$ & $2 \%$ & $3 \%$ & $10 \%$ & $7 \%$ & $4 \%$ & $2 \%$ \\
\hline Personal enrichment & $3 \%$ & $2 \%$ & $2 \%$ & $3 \%$ & $9 \%$ & $3 \%$ & $4 \%$ & $2 \%$ & $2 \%$ & $8 \%$ \\
\hline Observations & 31,083 & 1,837 & 1,548 & 8,170 & 6,549 & 21,112 & 1,979 & 749 & 3,610 & 3,934 \\
\hline
\end{tabular}

Note. Sample includes all first-time-in-college students who enrolled in an NCCCS college in 2002-03. EFC = expected family contribution. 